\title{
Perancangan Sistem Pakar untuk Penentuan Kesesuaian Jenis Palawija dan Kondisi Lahan
}

\author{
Endang Sulistiyani \\ Program Studi Sistem Informasi Universitas Nahdlatul Ulama Surabaya, Surabaya 60237 \\ E-mail: sulistiyani.endang@unusa.ac.id
}

\begin{abstract}
Abstrak
Peningkatan kualitas dan kuantitas komoditas pertanian dapat dilakukan dengan menghindari ketidaksesuaian pengolahan lahan dengan karakteristik lahan. Akan tetapi, tidak jarang petani mengalamai kesulitan dalam menentukan kesesuaian lahan. Hal ini dikarenakan pengetahuan dan pemahaman petani terkait karakteristik lahan yang akan diolah dan jenis tanaman yang ditanam masih kurang dan data yang benar terkait karakteristik lahan sulit diperoleh. Oleh karena itu dibutuhkan sistem pakar. Sistem dikembangkan dalam tiga langkah. Pertama, penggalian kebutuhan sistem pakar, kedua pembangunan sistem, dan terakhir pengujian sistem. Terdapat 5 faktor terkait karakteristik lahan, yaitu ketinggian tempat, temperatur udara, tekstur tanah, $\mathrm{pH}$ tanah, dan juga curah hujan untuk menentukan kesesuian jenis tanaman yang akan ditanam. Sistem ini memiliki 1080 aturan dengan 216 aturan untuk setiap tipe tanaman, dan 3 kemungkinan kesimpulan kesesuaian, yaitu sesuai, kurang sesuai, dan tidak sesuai. Hasil validasi untuk sistem ini berupa nilai rata-rata untuk masing-masing kategori yang menunjukkan bahwa responden setuju, baik terhadap fungsionalitas sistem bernilai 2,8. Keakuratan hasil kesimpulan yang dihasilkan oleh sistem bernilai 2,9 untuk hasil sesuai dengan kenyataan dan bernilai sebesar 3,0 untuk hasil membantu pengguna, serta untuk kepuasan dari responden untuk keseluruhan sistem pakar bernilai 2,9. Sementara untuk tampilan dari sistem pakar masih terlalu standar dan kurang menarik bernilai 2,6.
\end{abstract}

Kata Kunci: Sistem pakar, Kesesuaian, Palawija, Jenis lahan.

\section{PENDAhUluan}

Sebagai salah satu sektor industri, pertanian memiliki peranan penting terkait ketahanan pangan bagi kehidupan manusia. Ketahanan pangan nasional saat ini terencam oleh adanya luas lahan sawah irigasi di Jawa yang menyusut, produksi dan produktifitas melandai, perubahan iklim yang tidak mendukung, serta Organisme Pengganggu Tanaman (OPT) yang menyerang (Mulyani, 2001). Sebagai organisasi dunia yang menangani permasalahan terkait pertanian, Food and Agriculture Organisation (FAO) menetapkan strategic framework yang bertujuan untuk mengatasi kekurangan pangan dunia dengan memasukkan informasi sebagai salah satu elemen kuncinya (Salokhe, 2004). Oleh karenanya, lahan yang tersedia perlu dimanfaatkan dengan sebaik mungkin guna meningkatkan kualitas dan kuantitas komoditas pertanian.

Peningkatan kualitas dan kuantitas komoditas pertanian dapat dilakukan dengan menghindari ketidaksesuaian pengolahan lahan dengan karakteristik lahan. Karena ketidaksesuaian ini dapat menghambat proses bercocok tanam dan menyebabkan gagal panen sehingga secara tidak langsung peningkatan kualitas dan kuantitas komoditas pertanian tidak tercapai (Prasetyo, 2006).

Akan tetapi, tidak jarang petani mengalamai kesulitan dalam menentukan kesesuaian lahan. Hal ini dikarenakan pengetahuan dan pemahaman petani terkait karakteristik lahan yang akan diolah dan jenis tananman yang ditanam masih kurang dan data yang benar terkait karakteristik lahan sulit diperoleh. Dibutuhkan waktu yang tidak sebentar dan biaya yang tidak kecil untuk 
mendapatkan semua pengetahuan yang dibutuhkan. Apabila semuanya terbatas waktu dan biaya, maka sistem pendukung keputusan yang terkomputerisasi dibutuhkan (Amien, Nopember 1997).

Keputusan terkait apa dan bagaimana sebaiknya pemanfaatan lahan yang dilakukan oleh petani perlu dibantu dengan adanya sistem pakar (Wai, 2005). Penentuan kesesuaian lahan oleh petani dan proses penyebaran informasi dan pengetahuan melalui aplikasi yang dapat dikses kapan saja, dimana saja, serta dengan jangkauan yang lebih luas dapat terbantu dengan keberadaan sistem pakar ini.

Pembuatan sebuah Sistem Pakar Untuk Menentukan Kesesuain Jenis Tanaman Palawija dengan Jenis Lahan Yang Tersedia menjadi tujuan penelitian ini. faktor penghambat, saran manajerial untuk mengatasi faktor penghambat, dan lokasi yang sesuai bagi tanaman palawija tertentu dapat diidentifikasi oleh sistem pakar ini. Harapannya, dampak risiko kesalahan pemilihan jenis tanaman palawija yang akan ditanam pada suatu lahan tertentu dapat dikurangi dengan adanya perbandingan kondisi lahan dengan persyaratan tumbuh tanaman melalui penelitian ini.

\section{METODOLOGI}

Guna mengembangkan sistem pakar, penelitian ini dilaksanakan dalam 3 langkah utama. Pertama, penggalian kebutuhan sistem pakar, kedua pembangunan sistem, dan terakhir pengujian sistem. Detail metodologi penelitian disajikan pada Gambar 1.

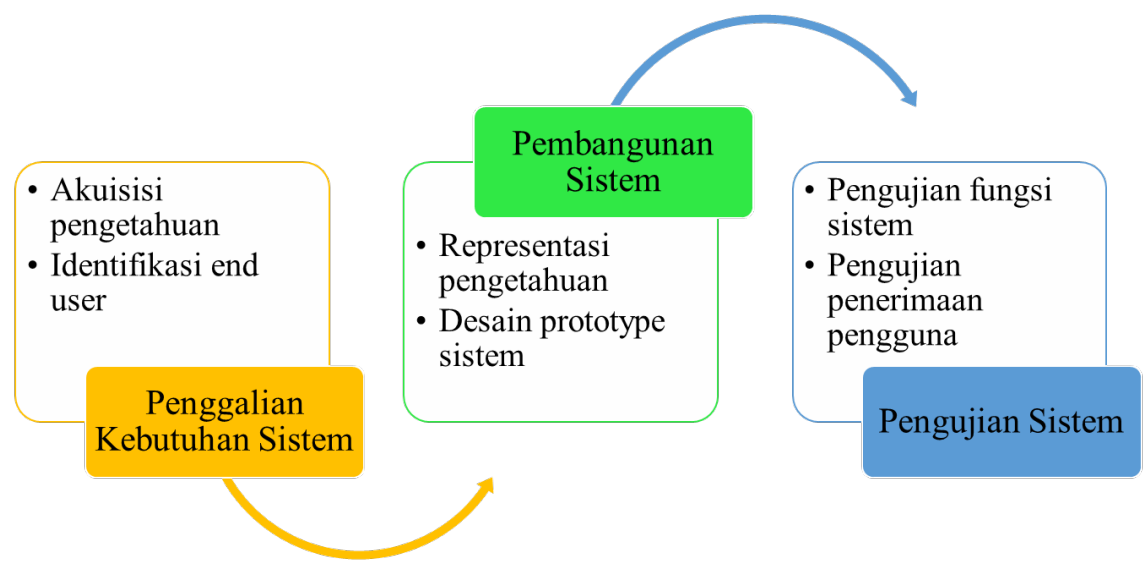

Gambar 3. Metodologi Penelitian

Tahapan pertama terdiri dari 2 hal, yakni akuisisi pengetahuan dan identifikasi pengguna akhir. Akuisisi pengetahuan sistem pakar dilakukan menggunakan dua metode, yaitu wawancara dengan pakar dan analisa dokumen terkait. Narasumber yang dipilih sebagai pakar adalah pengurus urban farming ITS dan dinas pertanian. Sementara dokumen yang dianalisa adalah Data penyuluhan Dinas Pertanian dan Makalah dengan judul "PENENTUAN PEMANFAATAN LAHAN - Kajian Land Use Planning. Penentuan pengguna akhir sistem didasarkan pada permasalahan yang dijelaskan pada latar belakang, yakni kesulitan petani dalam menentukan jenis tanaman yang tepat ditanam berdasarkan jenis lahan yang tersedia karena kurangnya pengetahuan yang dimiiki.

Tahapan pembangunan sistem dimulai dengan representasi pengetahuan yang telah diperoleh dari proses akuisisi. Representasi pengetahuan dapat berupa fakta dan juga aturan. Prototype dari sistem pakar dibuat menggunakan tools McGoo (IS Bulider) karena adanya kebutuhan node (aturan) sebanyak 1080 yang didukung oleh McGoo (McGoo, 2009). Desain arsitektur sistem pakar dan inferencing menjadi bagian dalam pembangunan sistem. Desain arsitektur mendeskripsikan isi dari komponen sistem pakar, yaitu knowledge base, database, inferenceengine, user interface, explanation facilities. Sementara Inferencing dilakukan dengan metode 
Backward Chaining, yang cara kerjanya lebih pada memastikan apakan tanaman yang ditanam oleh user telah sesuai dengan kondisi lahan yang dimiliki.

Tahapan terakhir adalah pengujian sistem yang meliputi dua hal, yaitu pengujian fungsi sistem dan penerimaan pengguna. Pengujian fungsi sistem dilakukan dengan bantuan beberapa test case yg sudah dipersiapkan. Sedangkan pengujian yang bertujuan untuk melihat penerimaan pengguna menggunakan bantuan kuesioner yang akan diberikan kepada pengguna yang telah mencoba sistem pakar ini dan akan memberikan penilaiannya melalui kuesioner yang dibagikan.

\section{HASIL DAN PEMBAHASAN}

A. Penggalian kebutuhan

Akuisisi pengetahuan melalui wawancara dan analisa dokumen menghasilkan 3 faktor yang digunakan untuk mengidentifikasi dan mengevaluasi lahan, yaitu topografi, iklim, dan tanah. Berdasarkan wawancara dengan pakar, penentuan tanaman yang akan ditanam biasanya dilihat terlebih dahulu kondisi lahan dan kondisi lingkungan sekitar. Kondisi lahan bisa meliputi tekstur, kedalaman, dan drainase tanah. Sedangkan kondisi lingkungan meliputi ketersediaan perairan, kerentanan bencana, dan juga temperatur udara (Djaenuddin, 2003).

Toporafi yang dimaksud terkait evaluasi lahan adalah bentuk wilayah dan ketinggian tempat di atas permukaan laut. Faktor iklim ini berkitan dengan suhu udara dan curah hujan. Apabila data suhu ini tidak tersedia, suhu udara diperkirakan berdasarkan ketinggian tempat dari permukaan laut. Sementara itu curah hujan untuk keperluan penilaian kesesuaian lahan biasanya dinyatakan dalam jumlah curah hujan tahunan yaitu jumlah bulan kering dan jumlah bulan basah. Faktor kondisi tanah dalam evaluasi kesesuaian lahan dilihat dari beberapa sifat dan karakteristik tanah diantaranya drainase tanah, tekstur, kedalaman, retensi hara, bahaya erosi, dan $\mathrm{pH}$. Tekstur merupakan kombinasi partikel halus tanah, aitu pasir, debu, dan liat.

Pengguna akhir dari sistem pakar ini adalah lembaga/organisasi petani. Dengan memanfaatkan sistem pakar ini, para petani dapat menganalisa lahan yang mereka miliki dan menentukan tanaman apa yang akan ditanam sesuaid dengan kondisi lahan yang dimilikinya. Selain itu, sistem pakar ini juga dapat dimanfaatkan oleh pihak lain untuk membantu petani yang kurang mampu memanfaatkan teknologi. Pihak lain nantinya dapat menjadi perantara bagi petani untuk mengolah kondisi lahan yang disampaikan oleh petani dan memprosesnya pada sistem pakar. Pihak lain ini dapat berupa mahasiswa.

\section{B. Pembangunan Sistem Pakar}

Pengetahuan yang diperoleh dari proses akuisisi, baik melalui pakar secara langsung maupun literatur berbentuk buku selanjutnya direpresentasikan guna menjadi acuan dalam pembangunan sistem pakar. Representasi pengetahuan berupa fakta dan juga aturan. Pada pengembangan sistem pakar ini, pengetahuan yang diperoleh direpresentasikan dalam tiga hal, yaitu fakta dari karakteristik lahan yang berpengaruh pada jenis tanaman, aturan untuk karakteristik lahan yang sesuai dengan tanaman, dan juga fakta dari aturan yang ada.

Beberapa karakteristik lahan yang mempengaruhi jenis tanaman palawija yang akan ditanam beserta bilangan linguistik dan kisaran datanya disajikan pada Tabel 1.

Tabel 1. Data Karakteristik Lahan

\begin{tabular}{|c|c|c|}
\hline Karakteristik lahan & Nilai linguistik & Kisaran data \\
\hline Ketinggian tempat & Dataran rendah & $<=700$ \\
\cline { 2 - 3 }$(\mathrm{m} \mathrm{dpl})$ & Dataran tinggi & $>700$ \\
\hline $\begin{array}{c}\text { Temperatur udara } \\
(\mathrm{oC})\end{array}$ & Dingin & $<17$ \\
\cline { 2 - 3 } & Sejuk & $18-25$ \\
\hline
\end{tabular}




\begin{tabular}{|c|c|c|}
\hline Karakteristik lahan & Nilai linguistik & Kisaran data \\
\hline & Hangat & $26-35$ \\
\hline & Panas & $>=36$ \\
\hline \multirow{3}{*}{ Curah hujan (mm) } & Rendah & $<300$ \\
\hline & Sedang & $301-1600$ \\
\hline & Tinggi & $>1601$ \\
\hline \multirow{3}{*}{$\mathrm{pH}$} & Asam & $<6$ \\
\hline & Netral & $6.1-7.8$ \\
\hline & Basa & $>7.9$ \\
\hline \multirow{3}{*}{ Tekstur } & $\operatorname{Kasar}(\mathrm{k})$ & Pasir atau pasir berlempung \\
\hline & Halus (h) & $\begin{array}{l}\text { lempung berpasir sangat halus, lempung, } \\
\text { lempung debu, debu }\end{array}$ \\
\hline & Lembut (1) & Liat berpasir, liat, atau liat berdebu \\
\hline
\end{tabular}

Berdasarkan data pada Tabel 1 terlihat bahwa, terdapat lima karakteristik lahan yang berpengaruh pada kesesuaian penanaman jenis tanaman palawija, yaitu ketinggian tempat, temperature udara, curah hujan, $\mathrm{pH}$, dan tekstur tanah. Terdapat dua faktor utama yang menentukan kesesuaian tanaman dengan kondisi lahan, yaitu ketinggian tempat dan temperatur udara.

Sementara itu aturan untuk kesesuaian jenis tanaman palawija dengan kondisi lahan sebanyak 1080 dengan rincian 216 untuk setiap jenis tanaman palawija. Rangkuman aturan disajikan pada Tabel 2.

Tabel 2. Atran Kesesuaian Jenis Palawija dan Lahan

\begin{tabular}{|c|l|}
\hline $\begin{array}{c}\text { Nama } \\
\text { Tanaman }\end{array}$ & Rule yang Sesuai \\
\hline \multirow{5}{*}{ Jagung } & IF Jenis Tanaman Jagung \\
& AND ketinggian dataran rendah atau dataran tinggi \\
& AND tekstur tanah kasar atau halus \\
& AND temperatur udara pada lahan Anda adalah sejuk atau \\
& hangat \\
& AND pH asam atau netral \\
& AND curah hujan rendah atau sedang atau tinggi \\
& THEN SESUAI \\
\hline \multirow{5}{*}{ Kedelai } & IF Jenis Tanaman Kedelai \\
& AND ketinggian dataran rendah atau dataran tinggi \\
& AND tekstur tanah kasar dan halus atau lembut \\
& AND temperatur udara pada lahan Anda adalah sejuk atau \\
& hangat \\
& AND pH asam atau netral \\
& AND curah hujan sedang \\
& THEN SESUAI \\
\hline Tembakau & IF Jenis Tanaman Tembakau \\
& AND ketinggian dataran rendah atau dataran tinggi \\
& AND tekstur tanah kasar dan halus atau lembut \\
& AND temperatur udara pada lahan Anda adalah sejuk atau \\
& hangat \\
& AND pH asam atau netral \\
& AND curah hujan sedang atau tinggi \\
\hline
\end{tabular}




\begin{tabular}{|l|l|}
\hline & THEN SESUAI \\
\hline \multirow{5}{*}{ Cabai } & IF Jenis Tanaman cabai \\
& AND ketinggian dataran rendah atau dataran tinggi \\
& AND tekstur tanah kasar atau halus \\
& AND temperatur udara pada lahan Anda adalah sejuk atau hangat \\
& AND pH netral \\
& AND curah hujan sedang \\
& THEN SESUAI \\
\hline \multirow{5}{*}{ Kacang tanah } & IF Jenis Tanaman Kacang Tanah \\
& AND ketinggian dataran rendah \\
& AND tekstur tanah kasar atau halus \\
& AND temperatur udara pada lahan Anda adalah hangat \\
& AND pH netral \\
& AND curah hujan sedang \\
& THEN SESUAI \\
\hline
\end{tabular}

\section{Pengujian Sistem}

Validasi sistem pakar dilakukan dengan membuat test case terhadap aturan pada sistem pakar. Test case berisi jenis palawija yang ingin ditanam beserta kondisi lahan yang tersedia, mulai dari ketinggian, tekstur, temperature, $\mathrm{pH}$, dan curah hujan. Contoh rencana test case yang digunakan pada pengujian validasi sistem pakar disajikan pada Tabel 3.

Tabel 3. Contoh Rencana Test Case

\begin{tabular}{|c|l|}
\hline User & \multicolumn{1}{|c|}{ Test case } \\
\hline 1 & $\begin{array}{l}\text { Tanaman cabai (dataran rendah, tekstur tanah halus, temperature udara hangat, pH netral dan } \\
\text { curah hujan sedang) }\end{array}$ \\
\hline 2 & $\begin{array}{l}\text { Tanaman kacang (dataran rendah, tekstur tanah halus, temperature udara hangat, pH netral } \\
\text { dan curah hujan sedang) }\end{array}$ \\
\hline 3 & $\begin{array}{l}\text { Kedelai (dataran rendah, tekstur tanah halus, temperature udara hangat, pH netral dan curah } \\
\text { hujan sedang) }\end{array}$ \\
\hline 4 & $\begin{array}{l}\text { Tembakau (dataran rendah, tekstur kasar, temperature udara sejuk, pH netral dan curah hujan } \\
\text { sedang) }\end{array}$ \\
\hline 5 & $\begin{array}{l}\text { Cabai (dataran tinggi, tanah lembut, temperature udara sejuk, pH netral, dan curah hujan } \\
\text { sedang) }\end{array}$ \\
\hline
\end{tabular}

Sementara itu, untuk menghimpun data lebih detail terkait penerimaan pengguna terhadap sistem digunakan kuisioner sebagai metodenya. Dalam kuesioner ini terdapat beberapa pertanyaan yang berisikan penilaian terhadap sistem pakar ini. Contoh kuesionernya disajikan pada Tabel 4.

Tabel 10 Contoh Kuesioner Penerimaan Pengguna

\begin{tabular}{|c|c|c|c|c|c|}
\hline \multicolumn{6}{|c|}{$\begin{array}{l}\text { Nama } \quad: \\
\text { Status } \quad: \\
\text { Apakah Anda memiliki keluarga petani? Ya | Tidak } \\
\text { Keterangan }\end{array}$} \\
\hline \multicolumn{6}{|c|}{ STS : Sangat Tidak Setuju $\mid$ TS : Tidak Setuju $\mid$ S : Setuju $\mid$ SS : Sangat Setuju } \\
\hline \multirow{2}{*}{ No } & \multirow{2}{*}{ Pertanyaan } & \multicolumn{4}{|c|}{ Jawaban } \\
\hline & & STS & TS & $\mathbf{S}$ & SS \\
\hline 1 & Apakah sistem pakar ini mudah digunakan? & & & & \\
\hline
\end{tabular}




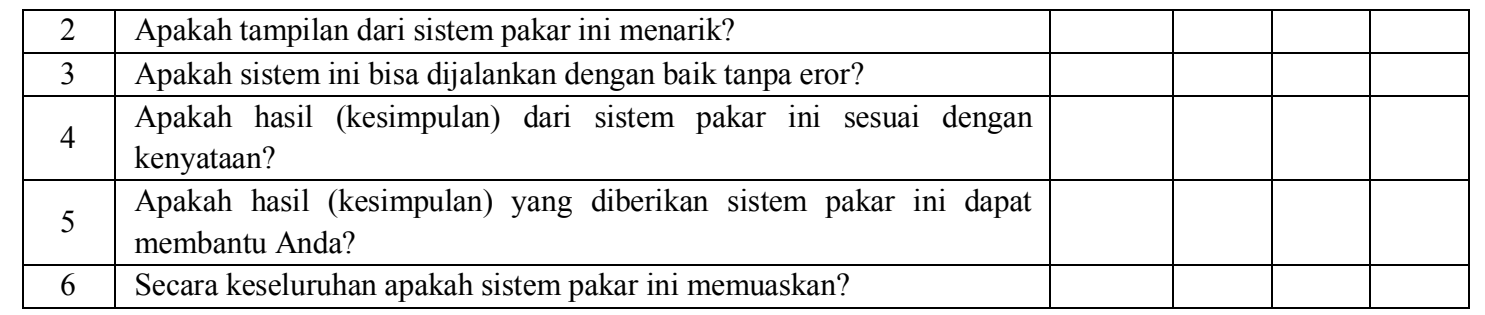

Kuesioner disebarkan kepada kepada 40 responden. Berikut adalah hasil kuesioner yang telah dilakukan dan telah dikonversi hasilnya kedalam bentuk nilai (lihat Tabel 5).

Sangat Tidak Setuju : 1

Tidak Setuju $\quad: 2$

Setuju : : 3

Sangat Setuju $\quad: 4$

Tabel 5. Hasil Rekap Kuesioner

\begin{tabular}{|l|c|c|c|c|c|c|c|}
\hline \multirow{2}{*}{ Nama } & \multicolumn{7}{c|}{ Pertanyaan } \\
\cline { 2 - 8 } & $\mathbf{1}$ & $\mathbf{2}$ & $\mathbf{3}$ & $\mathbf{4}$ & $\mathbf{5}$ & $\mathbf{6}$ & $\mathbf{7}$ \\
\hline Bekti & YA & 3 & 3 & 3 & 3 & 3 & 3 \\
\hline Saifu & YA & 3 & 2 & 3 & 3 & 2 & 3 \\
\hline$\ldots \ldots \ldots \ldots \ldots \ldots \ldots \ldots \ldots \ldots \ldots \ldots \ldots \ldots$ & $\ldots \ldots \ldots$ & $\ldots \ldots$ & $\ldots \ldots$ & $\ldots \ldots$ & $\ldots \ldots$ & $\ldots \ldots$. & $\ldots \ldots$ \\
\hline Hippo & TIDAK & 2 & 3 & 3 & 3 & 3 & 3 \\
\hline Hafi & TIDAK & 2 & 2 & 3 & 3 & 3 & 2 \\
\hline RATA-RATA & & $\mathbf{2 . 9}$ & $\mathbf{2 . 6}$ & $\mathbf{2 . 8}$ & $\mathbf{2 . 9}$ & $\mathbf{3 . 0}$ & $\mathbf{2 . 9}$ \\
\hline
\end{tabular}

Secara keseluruhan sistem pakar yang dibangun sudah menjawab permasalahan yang dihadapi oleh beberapa target pengguna. Hal ini dapat dilihat dari nilai rata-rata untuk masing-masing kategori menunjukkan bahwa responden setuju, baik terhadap fungsionalitas sistem, keakuratan hasil (kesimpulan) yang dihasilkan oleh sistem, dan juga kepuasan dari responden untuk keseluruhan sistem pakar. Sementara untuk tampilan dari sistem pakar masih terlalu standard dan kurang menarik. Hal ini didukung dengan banyaknya saran dari responden terkait perbaikan tampilan dari sistem.

\section{KESIMPULAN}

Kesimpulan berisi ringkasan hasil penelitian/kajian. Berdasarkan hasil penelitian diperoleh kesimpulan sebagai berikut:

1. Kesesuain jenis tanaman palawija dengan kondisi lahan yang tersedia dilihat dari 5 karakteristik lahan, yaitu ketinggian tempat, temperatur udara, tekstur tanah, $\mathrm{pH}$ tanah, dan juga curah hujan pada daerah tersebut.

2. Sistem pakar untuk menentukan kesesuain jenis tanaman dengan kondisi lahan yang tersedia dibuat dengan lima karakteristik lahan, 1080 aturan secara keseluruhan dengan rincian 216 aturan untuk masing-masing jenis tanaman, dan tiga kemungkinan hasil (kesimpulan) kesesuaian, yaitu sesuai, kurang sesuai, dan tidak sesuai.

3. Hasil validasi untuk sistem ini menujukkan nilai rata-rata untuk masing-masing kategori menunjukkan bahwa responden setuju, baik terhadap fungsionalitas sistem bernilai 2,8, keakuratan hasil kesimpulan yang dihasilkan oleh sistem bernilai 2,9 untuk hasil sesuai dengan kenyataan dan bernilai sebesar 3,0 untuk hasil membantu pengguna, dan juga kepuasan dari responden untuk keseluruhan sistem pakar bernilai 2,9. Sementara untuk tampilan dari sistem pakar masih terlalu standard dan kurang menarik bernilai 2,6. 
Guna mengembangkan sistem pakar ini kedepannya, terdapat beberapa saran yang didapatkan dari hasil pengerjaan penelitian ini, yaitu:

1. Diperlukan informasi tambahan pada bagian kesimpulan seperti informasi tanaman yang sesuai dengan jenis lahan tersebut, cara menanam tanaman tertentu dengan kondisi lahan yang ada serta beberapa informasi tambahan lainnya.

2. Pengembangan secara luas kedepannya, aplikasi ini dapat diintegrasikan dengan database lokasi lahan di Indonesia dan dijadikan sebagai salah satu rekomendasi lokasi lahan yang tepat untuk tanaman tertentu. Hal ini akan meningkatkan fungsionalitas sistem dan meningkatkan jumlah pengguna dengan kebutuhan yang lebih besar, seperti bisnis cocok tanam dengan memanfaatkan lahan yang tersedia di Indonesia.

3. Pemanfaatan Sistem Informasi Geografis (SIG) pada sistem ini juga dapat menjadi hal yang bisa dikembangkan kedepannya. Dengan memanfaatkan database lahan tadi, kategori lahan dapat divisualisasikan pada peta SIG untuk mempermudah pengguna menemukan lokasi lahan yang tepat.

\section{DAFTAR PUSTAKA}

[1] Amien, I., Sosiawan, H., dan Susanti, E. Agroekologi dan Alternatif Pengembangan Pertanian di Kalimantan. Prosiding Temu Konsultasi Sumberdaya Lahan Untuk Pembangunan Wilayah Kalimantan. 1997; 93-114.

[2] Djaenuddin, D. Petunjuk Teknis Evaluasi Lahan untuk Komoditas Pertanian. Bogor: Balai Penelitian Tanah, Pusat Penelitian dan Pengembangan Tanah dan Agroklimat, Badan Litbang Pertanian, Departemen Pertanian. 2003.

[3] McGoo. Diakses pada 25 Oktober 2014, www.McGoo.com/esbuilder/help/mainHelp.php

[4] Mulyani, A. Peluang Pemanfaatan Lahan Tidur Untuk Meningkatkan Produksi Tanaman Pangan di Indonesia. Jurnal Litbang Pertanian. 2001; 20(1): 9-16.

[5] Prasetyo BH, Suriadikarta DA. Karakteristik, Potensi, dan Teknologi Pengelolaan Tanah Ultisol Untuk Pengembangan Pertanian Lahan Kering di Indonesia. Jurnal Litbang Pertanian. 2006; 25(2): 39-46.

[6] Salokhe, G. FAO's Role in Information Management and Dissemination Challenges, Inovation, Success, Lesson Learned. 2004. Diakses pada Desember 2007, http://www.fao.org [7] Wai, K. S. dkk. Expert System in Real World Applications. 2005. Diakses pada Maret 2008, from http://www.generation5.com/ 